\title{
Immune Induction of Human Monocyte Plasminogen Activator. Characteristics of an Assay for Cell-Mediated Immunity ${ }^{1}$
}

\author{
Carol Godoshian Ragsdale ${ }^{* 2}$, Kenneth H. Swartz ${ }^{*}$ and James T. \\ Cassidy ${ }^{* * * *}$ \\ * Division of Rheumatology, Department of Pediatrics and Communicable Diseases and the ** Rackham \\ Arthritis Unit, Department of Internal Medicine, University of Michigan, Ann Arbor, MI 48109, U.S.A.
}

(Received 1 May 1984, accepted 4 January 1985)

We characterized immunologic induction of monocyte plasminogen activator (PA) to determine whether assay for PA induction reliably detected cell-mediated immunity (CMI). Mononuclear leukocytes (MNL) were incubated in teflon-lined culture tubes for 1-4 days in the presence or absence of phytohemagglutinin-P (PHA), concanavalin A (Con A) or Candida antigen. PA activity of the monocytes in those suspensions was then measured using a micro fibrin plate assay.

Monocytes in stimulated MNL had more PA activity than monocytes in unstimulated MNL. Maximal differences between stimulated and unstimulated cells were seen after 2 days of culture. Dose-response studies demonstrated that PA induction occurred at submitogenic concentrations of stimuli. Peak induction was seen using suboptimally mitogenic concentrations of PHA, Con A and Candida antigen. PA induction in response to Candida stimulation corresponded with skin test results. More than $90 \%$ of healthy adults tested had positive assays to all stimuli. LPS, in picogram concentrations, induced PA activity in the absence of lymphocytes, but such induction was prevented by polymyxin $B$.

Supernates from activated MNL also induced PA in purified monocytes. This indirect assay of PA induction was less sensitive than direct assay of the MNL. A standard indirect assay for leukocyte inhibitory factor (LIF) was also less sensitive than the direct PA induction assay.

The direct PA induction assay is sensitive and convenient and requires small volumes of blood. It may prove valuable in in vitro analysis of cell-mediated immunity in health and disease.

Key words: cell-mediated immunity - lymphokines

\footnotetext{
1 Supported in part by PHS Grant AM20557 and by the Arthritis Foundation.

2 Address correspondence to: Dr. C.G. Ragsdale, K1011 Holden, Box 07, Department of Pediatrics and Communicable Diseases, University of Michigan Medical School, Ann Arbor, MI 48109, U.S.A.

Abbreviations: Con A, concanavalin A; DME-LH, Dulbecco's modified Eagle's medium (Gibco) containing penicillin $(100 \mathrm{U} / \mathrm{ml})$, streptomycin $(100 \mu \mathrm{g} / \mathrm{ml}), 25 \mathrm{mM}$ Hepes buffer and $0.05 \%$ lactalbumin hydrolysate; HBSS, Hanks' buffered salt solution; JRA, juvenile rheumatoid arthritis; LIF, leukocyte inhibitory factor; LPS, lipopolysaccharide; LT, lymphocyte transformation; MIF, macrophage inhibitory factor; MNL, mononuclear leukocyte(s); PA, plasminogen activator; PBS, phosphate-buffered saline; PHA, phytohemagglutinin-P; RPMI, RPMI 1640 medium (Gibco) containing penicillin (100 U/ml), streptomycin $(100 \mu \mathrm{g} / \mathrm{ml})$ and $25 \mathrm{mM}$ Hepes buffer.
} 


\section{Introduction}

In evaluating the integrity of the immune response, or in analyzing specific immune reactivity in health and disease, in vitro assays of lymphokine activity have been important complements to skin testing or assay of lymphocyte transformation. Such assays usually measure inhibition of migration of mononuclear phagocytes (MIF) or neutrophils (LIF), and they have sometimes been the only suitable assays for detecting immune reactivity. They are not in wide or routine use, however, because the techniques are cumbersome and often insensitive.

Observations of others have shown that one effect of stimulating mononuclear leukocytes in vitro is to enhance or induce secretion of plasminogen activator in monocytes or macrophages (Klimetzek and Sorg, 1977; Vassalli and Reich, 1977; Greineder, et al., 1979). It has been suggested that measurement of PA induction might be a useful measure of lymphokine production. In this work immune induction of monocyte PA has been characterized to define requirements for reliably detecting lymphokine secretion. In addition, cell culture and enzyme assay methods have been developed that require small volumes of blood.

\section{Materials and Methods}

\section{Preparation of cultureware}

Teflon solar film 100A (Chemplast, Wayne, $\mathrm{NJ}$ ) was cut into $8 \mathrm{~cm}$ squares using a knife and straight edge. The squares were soaked overnight in detergent, rinsed thoroughly in water and ethanol and dried under an infrared lamp. A square was wrapped around the end of a $10 \times 75 \mathrm{~mm}$ glass tube, taped, and autoclaved. The wrapped tube was inserted into a sterile plastic $12 \times 75 \mathrm{~mm}$ culture tube (Falcon), with removal of the tape. The inner glass tube was removed, leaving a sterile teflon culture surface. When serum or medium was added the micropipettor was used to align the teflon folds conically (Fig. 1).

For assay of PA activity human fibrinogen (Calbiochem) was purified, depleted of plasminogen and iodinated (Gordon et al., 1976). ${ }^{125}$ I-fibrin-coated microtiter plates were prepared using the method of Klimetzek and Sorg (1977).

\section{Purification of leukocytes}

Mononuclear leukocytes (MNL) were purified by Ficoll-Hypaque centrifugation of whole blood anti-coagulated with preservative-free heparin $(10 \mathrm{U} / \mathrm{ml})$. Fifteen to $25 \%$ of the MNL were monocytes as determined by staining for non-specific esterase and $1 \%$ of Wright-stained cells were neutrophils.

Purified $\mathrm{B}$ and $\mathrm{T} /$ null cell suspensions were prepared by elution from nylon-wool columns (Sher et al., 1985). T/null cell suspensions were free of cells staining for surface immunoglobulin or non-specific esterase. More than $90 \%$ of B suspensions stained for surface immunoglobulin and fewer than $5 \%$ were monocytes. More than $90 \%$ of the cells in freshly isolated suspensions excluded trypan blue and more than $70 \%$ excluded the dye after 2 days of culture. 
1.

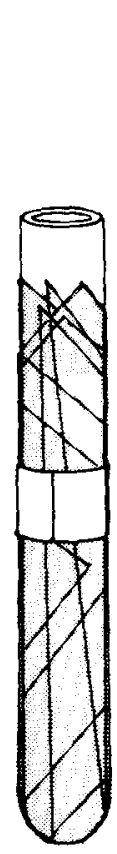<smiles>ICCCCCI</smiles>

3.

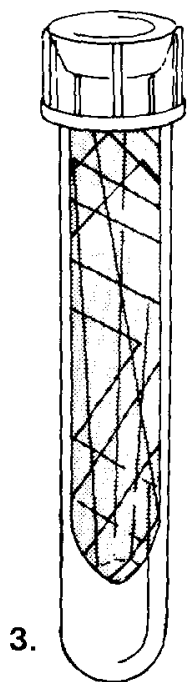

2.
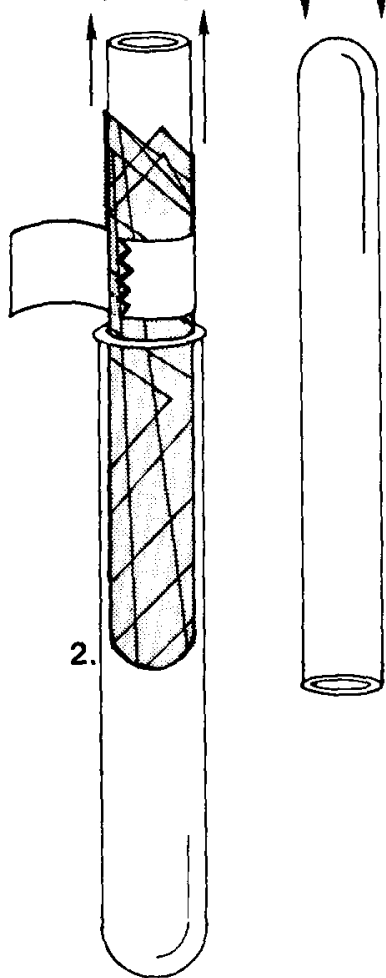

Fig. 1. Method for lining culture tubes with teflon: (1) a $10 \times 75 \mathrm{~mm}$ tube is wrapped with teflon film and autoclaved; (2) the wrapped tube is inserted into a $12 \times 75 \mathrm{~mm}$ culture tube; the tape and the glass tube are removed; (3) the completed culture vessel.

Monocytes were purified using a modification of the method of Ackerman and Douglas (1978). MNL were incubated for $1 \mathrm{~h}$ in $100 \mathrm{~mm}$ culture plates coated with gelatin. The plates were gently washed with warm HBSS to remove non-adherent cells and incubated for $20 \mathrm{~min}$ at $37^{\circ} \mathrm{C}$ in RPMI 1640 culture medium (RPMI) containing $3 \mathrm{mM}$ EDTA and $20 \% \mathrm{AB}+$ serum. With gentle aspiration through a pipette, the adherent cells were suspended, washed and resuspended in RPMI. Seventy to ninety percent of these cells were monocytes. No neutrophils were present.

PMN were purified from whole blood after Ficoll-Hypaque centrifugation, dextran sedimentation and hypotonic lysis of red cells and were used to assay for leukocyte inhibitory factor (LIF). 
Culture of MNL or monocytes

$\mathrm{AB}+\operatorname{serum}(0.15 \mathrm{ml})$ was added to the teflon-lined tubes, then $0.75 \mathrm{ml}$ of RPMI was added along with antigen or mitogen. Polymyxin $\mathrm{B}(2 \mu \mathrm{g} / \mathrm{ml})$ was added to some cultures. $1 \times 10^{6} \mathrm{MNL}$ in a volume of $0.1 \mathrm{ml}$ were added; the tubes were loosely capped and incubated for $1-4$ days at $37^{\circ} \mathrm{C}$ in $5 \% \mathrm{CO}_{2}$ prior to assay of enzyme activity.

In some experiments, stimulated or unstimulated MNL were cultured at $1 \times$ $10^{6} / \mathrm{ml}$ in conical plastic tubes in RPMI for 2 days. After incubation unstimulated cultures were reconstituted with antigen or mitogen and centrifuged for $10 \mathrm{~min}$ at $400 \times \mathrm{g}$. The supernates were recovered and frozen at $-20^{\circ} \mathrm{C}$ until used further. Purified monocytes $\left(3-5 \times 10^{5}\right)$ were incubated for 2 days in supernates made to contain $15 \%$ serum. PA activity of these preparations was then measured.

\section{Assay of $P A$ activity}

MNL or purified monocytes were recovered from the teflon-lined culture tubes and centrifuged at $200 \times \mathrm{g}$ for $10 \mathrm{~min}$. The cell pellet was resuspended in $1.0 \mathrm{ml}$ Dulbecco's modified Eagle's medium containing $0.05 \%$ lactalbumin hydrolysate (DME-LH), and $100 \mu \mathrm{l}$ was reserved for enumeration of monocytes. Aliquots of 100 $\mu 1$ were added to $100 \mu \mathrm{l}$ DME-LH in microtiter wells (Falcon) coated with ${ }^{125}$ I-fibrin. Plasminogen was added to half of 6 wells and the plates were incubated at $37^{\circ} \mathrm{C}$ for $3 \mathrm{~h}$. At the end of the assay period the supernates were aspirated from the wells using a multichannel pipettor and counted in a gamma counter. The substrate of 12 wells that had contained no cells was digested with trypsin and similarly counted for determination of total radioactivity. Fibrinolysis was calculated as the percentage of the substrate solubilized during the assay period. Replicate cultures varied by less than $15 \%$ from their mean. Units of PA activity were obtained by dividing the percent fibrinolysis by the number of monocytes $\left(\times 10^{3}\right)$ per well. PA induction was also normalized by expressing enzyme activity in stimulated cultures as a percentage of control unstimulated activity.

\section{Enumeration of monocytes}

Monocytes were counted using Technicon staining reagents as described by Tucker et al. (1977). To the reserved aliquot of MNL was added $100 \mu 1$ PBS and 100 $\mu 1$ buffered fixative. Then $0.4 \mathrm{ml}$ of $\alpha$-naphthyl butyrate staining solution was added and the mixture incubated in a $37^{\circ} \mathrm{C}$ water bath for $7 \mathrm{~min} .0 .4 \mathrm{ml}$ of the stained MNL was then microfuged for $15 \mathrm{~s}$, and all but $25 \mu \mathrm{l}$ of the solution removed. The pellet of stained cells was resuspended and the monocytes were counted. When purified monocytes were added in known amounts to nylon wool purified lymphocytes and then counted, $75-99 \%$ of the cells were detected.

\section{Data analysis}

Enzyme activity in unstimulated cultures varied by a factor of 10 from day to day and from donor to donor, as has been reported for this system (Granelli-Piperno et al., 1977). Examination of the data revealed that they were not normally distributed, either when expressed as units of PA activity or when activity was expressed in 
'percent of control' terms. Enzyme activity is described in tables using the mean and standard deviation, to conveniently illustrate the dispersion of the raw data. Statistical analysis of PA induction, however, was performed using non-parametric tests. Analysis of differences in PA activity in stimulated and unstimulated cultures was performed using Wilcoxsin's rank sum test for matched pairs. To avoid bias introduced by testing donors more than once, only the first experiment for each individual was included in analysis. Differences in the occurrence of positive responses in children, patients and adults was evaluated using Fisher's exact test.

\section{Assay for LT and LIF}

For assay of lymphocyte transformation (LT), MNL at $5 \times 10^{5} / \mathrm{ml}$ were added in $0.2 \mathrm{ml}$ aliquots to microtiter wells in RPMI containing $15 \% \mathrm{AB}+$ serum in the presence or absence of PHA (Difco) $(0.2-50 \mu \mathrm{g} / \mathrm{ml})$, Con A (Pharmacia) (0.1-50 $\mu \mathrm{g} / \mathrm{ml}$ ) or Candida (Hollister Stier) $(1: 5000-1: 100)$. After incubation for 4 (mitogen) or 5 (antigen) days $0.5 \mu \mathrm{Ci}$ tritated thymidine was added to each well and $18 \mathrm{~h}$ later the cells were harvested, dried and counted in a scintillation counter.

Leukocyte inhibitory factor in $\mathrm{MNL}$ supernates was assayed by measuring inhibition of neutrophil migration under agarose (Gorski et al., 1975).

\section{Endotoxin assays}

Endotoxin assays were performed using a Limusate kit obtained from Calbiochem. LPS and polymyxin B were purchased from Sigma.

\section{Results}

Characteristics of $M N L$ cultured in teflon

When $10^{6} \mathrm{MNL}$ were cultured in teflon-lined tubes 5-7 $\times 10^{5}$ were recovered after 24-96 h. At initiation of culture, $20-25 \%$ of the MNL were monocytes as determined by staining for non-specific esterase, and after 2 days 10-20\% were monocytes. MNL viability after culture exceeded $98 \%$.

When MNL were assayed for PA activity after 2 days of culture, unstimulated cells from healthy adults solubilized $10 \pm 8 \%$ of the substrate, and unstimulated cells from 24 children aged 1-15 solubilized $9 \pm 6 \%$. The number of monocytes in unstimulated cultures was $8 \pm 5 \times 10^{3}$ per well during the enzyme assay. The addition of antigen or mitogen at low concentrations did not alter cell recovery. Con A at $2 \mu \mathrm{g} / \mathrm{ml}$ and PHA and Con A at $10 \mu \mathrm{g} / \mathrm{ml}$ or more caused some agglutination of the monocytes and a slight, statistically significant, reduction in numbers recovered after 2 days of culture.

When fibrinolysis was correlated with monocyte number, units of activity of unstimulated cultures ranged from 0.3 to 7 . Fibrinolysis of replicate unstimulated cultures varied by $8 \pm 8 \%$, when activity was correlated with monocyte number (10 experiments). An assay was considered 'positive' if enzyme activity induced in the presence of antigen or mitogen exceeded $130 \%$ of control unstimulated activity. 
Enhancement of PA production in monocytes by activated lymphocytes: the direct enzyme induction assay

Enhancement of PA activity over levels in unstimulated cultures regularly occurred after activation of MNL by mitogen or antigen. Increased enzyme activity was frequently observed $24 \mathrm{~h}$ after stimulation and differences between stimulated and unstimulated cultures were maximal after 2 days of culture. After 3 or 4 days, PA activity of unstimulated cultures increased and enhancement in stimulated cultures was inconsistently observed.

Dose-response studies determined that reactivity was best detected with lower concentrations of mitogen or antigen than were required to elicit lymphocyte transformation (LT) (Fig. 2). PA induction occurred using concentrations of PHA or Candida that induced no LT. Maximal PA induction occurred using suboptimally mitogenic concentrations of PHA or Con A. Higher concentrations, though optimally mitogenic (Fig. 1), often reduced PA activity. In such cultures monocyte recovery was slightly reduced, and the indicator cells were agglutinated. Inhibitors of PA induction were not detected when purified monocytes were incubated with supernates from more heavily stimulated cultures.

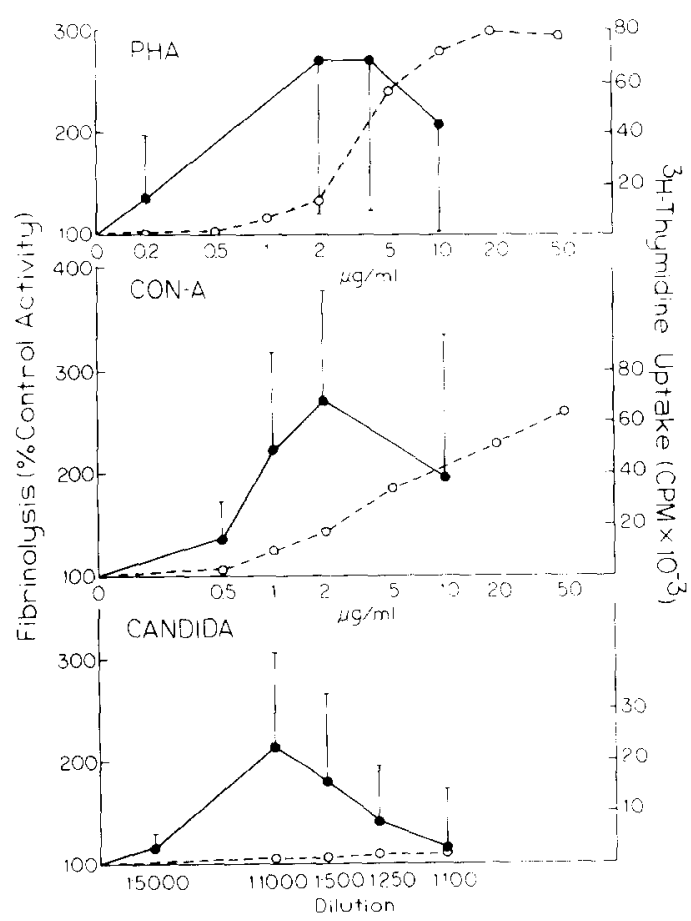

Fig. 2. MNL were obtained from the blood of healthy adults and cultured as described in Materials and Methods prior to assay of PA induction (—_- or LT (O_... ) . PA induction could be detected using concentrations of mitogen that did not induce lymphocyte transformation, and peak induction was seen at suboptimally mitogenic concentrations. Candida antigen induced PA activity without causing lymphocyte transformation. 


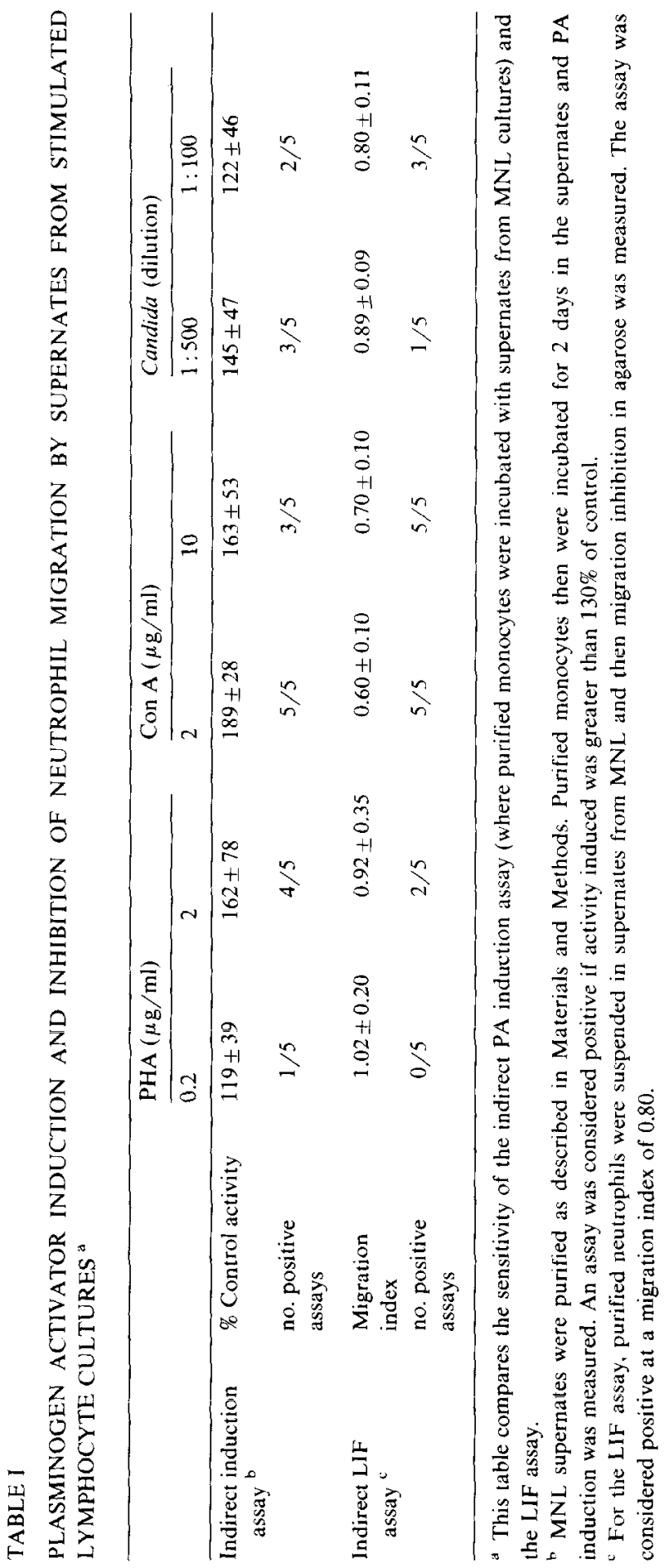


As has been observed (Greineder et al., 1979) induction of monocyte PA required lymphocytes or their soluble products. PHA, Candida or Con A, incubated with purified monocytes at concentrations used for direct induction, did not elicit increased PA secretion.

Neither purified $\mathrm{B}$ nor $\mathrm{T} /$ null cell suspensions were fibrinolytic either when freshly isolated or after mitogenic stimulation, or after incubation in supernates from stimulated MNL.

\section{The indirect induction assay}

MNL from 5 healthy donors were cultured for 2 days in RPMI in the presence or absence of mitogen or antigen. PA was induced by supernates from MNL incubated with all 3 stimulants (Table I). Sensitivity of this indirect induction assay equalled the sensitivity of an assay for LIF, but neither was as sensitive as the direct PA induction assay.

\section{Reactivity in health and disease}

Reactivity of healthy adults and hospitalized children to Con A, PHA and Candida was examined. Fifteen to 23 different healthy adults were tested in $20-46$ experiments. Individuals were tested 1-5 times.

In 46 assays (20 different adults) 23 assays showed reactivity to $0.2 \mu \mathrm{g} / \mathrm{ml}$ of PHA and 43 to $2 \mu \mathrm{g} / \mathrm{ml}$ of the mitogen. Repeat assays of the 3 non-reactive adults were positive. In $24 / 25$ assays using Con $\mathrm{A}(2 \mu \mathrm{g} / \mathrm{ml})$ and $21 / 23$ using Candida reactivity was observed. Reactivity is summarized in Table II. Whether or not an

\section{TABLE II}

PA INDUCING ACTIVITY OF MNL FROM HEALTHY ADULTS a

\begin{tabular}{lllll}
\hline $\begin{array}{l}\text { Stimulus } \\
\text { (concentration or dilution) }\end{array}$ & PA activity (units) & $P^{\mathrm{b}}$ & $\begin{array}{l}\text { g Control PA } \\
\text { activity }\end{array}$ & $\begin{array}{l}\text { no. positive } \\
\text { assays }\end{array}$ \\
\hline PHA $(0 \mu \mathrm{g} / \mathrm{ml})$ & $1.54 \pm 1.43$ & - & 100 & - \\
$(0.2)$ & $2.14 \pm 2.26$ & $<0.02$ & $144 \pm 60$ & $23 / 46(20)$ \\
$(2)$ & $3.27 \pm 2.22$ & $<0.001$ & $241 \pm 89$ & $43 / 46(20)$ \\
Con A $(0 \mu \mathrm{g} / \mathrm{ml})$ & $1.03 \pm 0.87$ & - & 100 & - \\
$(2)$ & $2.40 \pm 2.04$ & $<0.001$ & $270 \pm 149$ & $24 / 25(15)$ \\
$(10)$ & $2.56 \pm 2.25$ & $<0.02$ & $257 \pm 162$ & $14 / 20(15)$ \\
Candida $(0)$ & $1.90 \pm 1.53$ & - & 100 & - \\
$(1: 500)$ & $3.28 \pm 2.76$ & $<0.01$ & $187 \pm 85$ & $21 / 23(15)$ \\
\hline
\end{tabular}

a ML were incubated with or without antigen or mitogen for 2 days prior to measurement of enzyme activity.

b $p$ values were derived using Wilcoxsin's rank sum test for matched pairs (as described in Methods). Only 1 (the first) experiment from each donor was used in analysis.

c This column expresses activity in stimulated cultures as a percentage of control unstimulated activity $(\mathrm{M} \pm \mathrm{SD})$.

d Number of experiments where $130 \%$ of control activity was induced, a degree of enhancement exceeding variability of replicate unstimulated cultures. The number of different individuals tested is given in parentheses. 


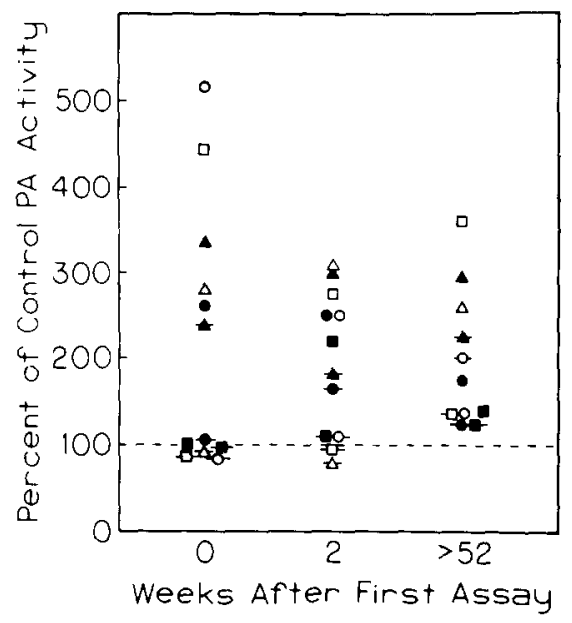

Fig. 3. Results of repeat assays of PA induction are illustrated for 6 consecutive healthy donors tested at the times indicated in the figure. MNL were cultured in the presence or absence of PHA at $0.2\left(-O_{-}\right)$or 2 (O) $\mu \mathrm{g} / \mathrm{ml}$ as described in Materials and Methods.

\section{TABLE III}

PA INDUCTION BY CANDIDA ALBICANS ANTIGEN a

\begin{tabular}{llll}
\hline $\begin{array}{l}\text { Patient } \\
\text { (sex, age) }\end{array}$ & Diagnosis & Candida \\
& & dkin test & $\begin{array}{l}\text { PA induction } \\
\text { in response to } \\
\text { Candida (\% control) }\end{array}$ \\
\hline $1(\mathrm{~F}, 34)$ & Healthy & + & 190 \\
$2(\mathrm{M}, 15)$ & CGD & + & 156 \\
$3(\mathrm{M}, 28)$ & CVI & + & 153 \\
$4(\mathrm{M}, 14)$ & CVI & + & 251 \\
$5(\mathrm{M}, 22)$ & Bruton's & + & 142 \\
$6(\mathrm{M}, 8)$ & CVI & + & 203 \\
$7(\mathrm{~F}, 52)$ & CVI & + & 221 \\
$8(\mathrm{~F}, 49)$ & CVI & + & 156 \\
$9(\mathrm{~F}, 4)$ & CMC & + & 146 \\
$10(\mathrm{~F}, 22)$ & Healthy & - & 106 \\
$11(\mathrm{M}, 26)$ & Bruton's & - & 91 \\
$12(\mathrm{M}, 12)$ & CVI & - & 121 \\
$13(\mathrm{M}, 7)$ & CVI & - & 98 \\
$14(\mathrm{~F})$ & Newborn & nd & 109 \\
$15(\mathrm{M})$ & Newborn & nd & 77 \\
$16(\mathrm{M})$ & Newborn & nd & 122 \\
\end{tabular}

${ }^{a}$ MNL were purified from whole blood and cultured with or without Candida antigen. PA activity was then measured as described in Materials and Methods.

b All individuals tested during 18 months for whom skin testing data could be obtained are included, except that newborns were not skin tested. Assays of cord blood included in the table had shown reactivity to both $\mathrm{PHA}$ and Con $\mathrm{A}$.

' Diagnoses: Bruton's, congenital agammaglobulinemia; CGD, chronic granulomatous disease; CMC, chronic mucocutaneous candidiasis; CVI, common variable immunodeficiency.

${ }^{d}$ Intradermal skin tests were read 2 days after application and scored as positive if both erythema ( $>5$ $\mathrm{mm})$ and induration $(>2 \mathrm{~mm}$ ) developed. 
individual showed reactivity to suboptimal concentrations of PHA or reduced activity to $10 \mu \mathrm{g} / \mathrm{ml}$ Con $\mathrm{A}$ tended to be constant on repeat testing over a year. Reactivity to PHA on repeat testing in 6 donors is illustrated in Fig. 3.

Among patients skin tested with Candida and assayed for reactivity to the antigen, 7 with positive skin tests all had positive assays ( $180 \pm 38 \%$ control); 4 with negative skin tests and 3 cord bloods had non-reactive assays (104 $\pm 16 \%$ of control) (Table III).

Infants and children displayed a lower degree of reactivity with a lower percentage of positive responses (Table IV). Cord bloods had low reactivity with 3 of 7 showing no reactivity to any stimulus. Children tested were hospitalized for elective cardiac catheterization or orthopedic or urologic surgery. The number of children taking digoxin, diuretics or antibiotics was small but reactivity of these patients did not differ from that of the other children. Children with active juvenile rheumatic arthritis (JRA), all of whom were treated with aspirin, reacted similarly to children with non-inflammatory diseases (Table IV). Six children with lupus (ages 7-16)

\section{TABLE IV}

\section{REACTIVITY OF INFANTS, CHILDREN AND ADULTS TO PHA, Con A OR CANDIDA "}

The occurrence of positive reactivity in children and adults was evaluated using Fisher's exact test. A significant difference was found between children and adults tested with $2 \mu \mathrm{g} / \mathrm{ml}$ Con A $(P<0.01)$. The entire group of JRA patients differed from adults when tested with $2 \mu \mathrm{g} / \mathrm{ml}$ PHA $(P<0.01)$ or $2 \mu \mathrm{g} / \mathrm{ml}$ Con A $(P<0.05)$. Reactivity of JRA children and children with non-inflammatory diseases did not differ by statistical analysis.

\begin{tabular}{|c|c|c|c|c|c|c|c|c|c|c|}
\hline & \multicolumn{4}{|c|}{ PHA $(\mu \mathrm{g} / \mathrm{ml})$} & \multicolumn{4}{|c|}{$\operatorname{Con} \mathrm{A}(\mu \mathrm{g} / \mathrm{ml})$} & \multicolumn{2}{|c|}{ Candida (dilution) } \\
\hline & $0.2^{b}$ & $\begin{array}{l}\text { no. } \\
\text { positive } \\
\text { assays }\end{array}$ & 2 & $\begin{array}{l}\text { no. } \\
\text { positive } \\
\text { assays }\end{array}$ & 2 & $\begin{array}{l}\text { no. } \\
\text { positive } \\
\text { assays }\end{array}$ & 10 & $\begin{array}{l}\text { no. } \\
\text { positive } \\
\text { assays }\end{array}$ & $1: 500$ & $\begin{array}{l}\text { no. } \\
\text { positive } \\
\text { assays }\end{array}$ \\
\hline $\begin{array}{l}\text { Healthy adults } \\
(20-50 \text { years })\end{array}$ & $\begin{array}{c}151 \pm \\
69\end{array}$ & $10 / 20$ & $\begin{array}{r}309 \pm \\
197\end{array}$ & $20 / 20$ & $\begin{array}{r}272 \pm \\
172\end{array}$ & $14 / 15$ & $\begin{array}{r}208 \pm \\
181\end{array}$ & $5 / 11$ & $\begin{array}{c}187 \pm \\
60\end{array}$ & $13 / 15$ \\
\hline \multicolumn{11}{|l|}{ Infants } \\
\hline (cord blood) & $\begin{array}{c}104 \pm \\
27\end{array}$ & $1 / 7$ & $\begin{array}{c}133 \pm \\
32\end{array}$ & $4 / 7$ & $\begin{array}{c}140 \pm \\
36\end{array}$ & $4 / 7$ & $\begin{array}{c}140 \pm \\
48\end{array}$ & $4 / 7$ & $\begin{array}{c}92 \pm \\
24\end{array}$ & $0 / 7$ \\
\hline $\begin{array}{l}\text { Children } \\
\qquad(1-15 \text { years })\end{array}$ & $\begin{array}{c}127 \pm \\
49\end{array}$ & $10 / 24$ & $\begin{array}{r}185 \pm \\
118\end{array}$ & $15 / 24$ & $\begin{array}{r}227 \pm \\
106\end{array}$ & $20 / 24$ & $\begin{array}{r}229 \pm \\
151\end{array}$ & $17 / 24$ & $\begin{array}{c}148 \pm \\
51\end{array}$ & $15 / 24$ \\
\hline $\begin{array}{l}\text { JRA children } \\
\text { systemic }\end{array}$ & $\begin{array}{c}229 \pm \\
91\end{array}$ & $3 / 3$ & $\begin{array}{r}231 \pm \\
118\end{array}$ & $4 / 4$ & $\begin{array}{c}177 \pm \\
97\end{array}$ & $2 / 4$ & $\begin{array}{c}215 \pm \\
84\end{array}$ & $3 / 3$ & $\begin{array}{c}184 \pm \\
93\end{array}$ & $2 / 3$ \\
\hline Pauciarticular & $\begin{array}{c}116 \pm \\
42\end{array}$ & $5 / 10$ & $\begin{array}{c}164 \pm \\
73\end{array}$ & $8 / 12$ & $\begin{array}{c}170 \pm \\
74\end{array}$ & $8 / 12$ & $\begin{array}{c}122 \pm \\
74\end{array}$ & $4 / 11$ & $\begin{array}{c}152 \pm \\
53\end{array}$ & $9 / 11$ \\
\hline Polyarticular & $\begin{array}{r}156 \pm \\
107\end{array}$ & $2 / 5$ & $\begin{array}{c}162 \pm \\
81\end{array}$ & $6 / 9$ & $\begin{array}{c}170 \pm \\
56\end{array}$ & $7 / 9$ & $\begin{array}{c}109 \pm \\
81\end{array}$ & $1 / 5$ & $\begin{array}{c}167 \pm \\
61\end{array}$ & $4 / 6$ \\
\hline
\end{tabular}

a MNL from cord blood or from patients were incubated for two days with or without mitogen or antigen prior to assay of enzyme induction. For healthy adults, the first assay performed was used in analysis. All children were tested only once. Children with JRA all had active disease; all were treated with aspirin.

b $P A$ activity is expressed in percent of control terms $(M \pm S D)$

c This column shows the number of assays where stimulated activity was greater than $130 \%$ of control activity. 
treated with prednisone in doses ranging from 0.2 to $1.5 \mathrm{mg} / \mathrm{kg}$ per day reacted to optimal concentrations of all 3 stimuli (not shown). Four children with the Down syndrome had non-reactive assays (not shown).

\section{Effects of endotoxin}

Unstimulated MNL cultured in certain batches of medium were observed to have high PA activity and stimulated MNL cultured in the same medium showed either no enhancement or reduction of PA activity. We investigated the possibility that endotoxin contaminating the medium was inducing PA.

Endotoxin content of culture medium was measured using a limulus lysate assay. Amounts equivalent to $1-50 \times 10^{-11} \mathrm{~g} / \mathrm{ml}$ of a standard LPS solution were found. Polymyxin B, which binds endotoxin (Morrison and Jacobs, 1976), blocked gelation of limulus lysate and reduced the high PA activity of cells cultured in stimulatory medium. RPMI was prepared in pyrogen-free water and contained less than $10^{-11}$ $\mathrm{g} / \mathrm{ml}$ of endotoxin. To purified monocytes or to MNL $10^{-11}-10^{-6} \mathrm{~g} / \mathrm{ml}$ of LPS were added and PA induction was determined.

The effects of LPS and polymyxin B on MNL and purified monocytes are illustrated in Fig. 3. At low concentrations $\left(10^{-10}-10^{-11} \mathrm{~g} / \mathrm{ml}\right)$ mononuclear leukocyte preparations and purified monocytes had enhanced PA activity which was blocked by addition of $2 \mu \mathrm{g} / \mathrm{ml}$ polymyxin $\mathrm{B}$. This result is consistent with a direct stimulation of the monocytes by PA. At high concentrations of LPS $\left(10^{-7}-10^{-6}\right.$ $\mathrm{g} / \mathrm{ml}$ ) PA activity decreased below control values and was restored to normal by

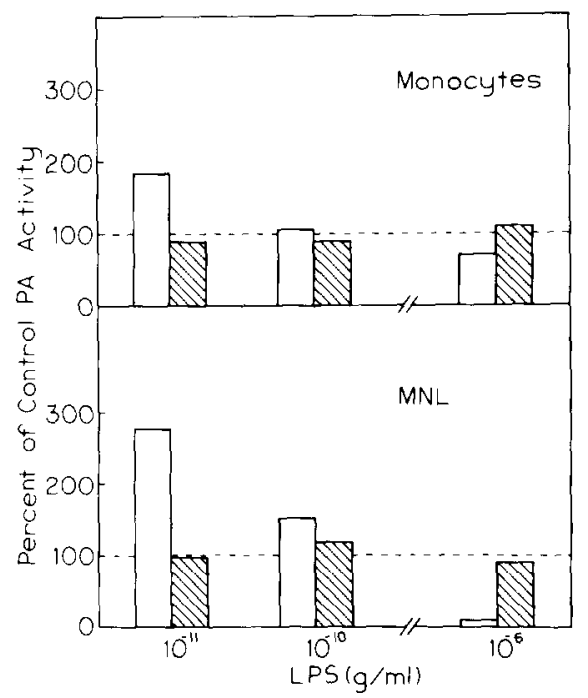

Fig. 4. Effects of LPS and polymyxin B on PA induction. Monocytes and MNL were purified as described in Materials and Methods and cultured in the presence or absence of LPS with or without polymyxin B for 2 days. In the absence of $2 \mu \mathrm{g} / \mathrm{ml}$ polymyxin B (plain bars) LPS in picogram concentrations induced PA activity in monocytes and MNL. Polymyxin B (hatched bars) prevented induction of PA by LPS. In microgram concentrations LPS reduced PA activity, which was restored by polymyxin $B$. 
polymyxin B (Fig. 4). MNL cultured in endotoxin-free medium and stimulated with PHA, Con A or Candida responded similarly in the presence or absence of polymyxin $\mathrm{B}$.

For some donors polymyxin B and concentrations of LPS ranging from $10^{-8}$ to $10^{-7} \mathrm{~g} / \mathrm{ml}$ induced PA activity over that of cultures containing polymyxin $\mathrm{B}$ alone (not shown). Such induction may represent a specific immune response to the LPS (Wood and Cameron, 1978).

\section{Discussion}

Assays for lymphokine secretion are important in the study of immune deficiency or immune reactivity in specific diseases. In this work lymphocyte and lymphokine enhancement of monocyte PA secretion have been studied to explore the utility of measuring PA induction as a sensitive assay of cell-mediated immunity.

Activated lymphocytes cultured directly with indicator monocytes in a direct enzyme induction assay induced enhanced secretion of PA over a period of 24-48 h. Over this same period PA secretion of purified monocytes was not induced by PHA, Candida or Con A. While Con A at $10 \mu \mathrm{g} / \mathrm{ml}$ has directly induced PA secretion in neutrophils (Granelli-Piperno et al., 1977) and murine macrophages (Vassalli et al., 1977) over several hours, this was not observed under the 2-day incubation conditions employed in these studies. It is possible that the agglutinating effect of the mitogen predominated over its PA stimulating effect, that PA secretion was suppressed, or that activation of the monocytes incubated without Con A occurred.

Lymphokine production can be detected by migration inhibition assays under conditions where lymphocyte transformation is not easily detected, and the direct enzyme induction assay also detected reactivity under such conditions. Healthy donors demonstrated PA induction in response to submitogenic or suboptimally mitogenic concentrations of mitogen or antigen. In addition, the direct enzyme induction assay was more sensitive than an LIF assay when the response to PHA or Candida, but not Con A, was measured. Even under conditions where LIF production is maximized, by culture of cells in conical tubes (McCoy et al., 1980), this indirect assay was less sensitive than the direct enzyme induction assay. The indirect enzyme induction assay, using human monocytes as indicator cells, was no more sensitive than the LIF assay.

Klimetzek and Sorg (1977) had observed that supernates from cultures of stimulated lymphocytes induced PA secretion in murine macrophages but that induction occurred over a narrow concentration range of lymphokines. In this work, PA induction over a narrow dose range of mitogen or antigen was observed, as PA induction was best elicited using suboptimally mitogenic concentrations of PHA or Con A. Monocyte agglutination may account for the reduction of PA activity in comparison with control cultures. Factors inhibitory to PA induction were not detected. It is possible that intense stimulation leads to secretion of protease inhibitors. Murine macrophages have been induced to secrete inhibitors of plasmin after prolonged exposure to lymphokines (Sorg et al., 1980). 
Endotoxin is a potent contaminant that can confound the PA induction assay. If picogram amounts contaminate cultures then PA activity of unstimulated cultures may be high and further stimulation by antigen or mitogen may not occur. Conversely, PA induction could be mistakenly interpreted when endotoxin contaminates an antigen preparation. Polymyxin B can block PA induction by low concentrations of endotoxin (Hamilton et al., 1982), and high concentrations ( $>10^{-9}$ $\mathrm{g} / \mathrm{ml}$ ) probably would not occur. The investigator using a PA induction assay, however, must be aware of the degree of endotoxin contamination of cultures.

In healthy adults immune reactivity was reliably detected on repeat testing and in a single test was absent in $10 \%$. Reactivity over a year was consistent. While the LIF was as reliable as the PA induction assay at detecting reactivity to Con A, Candida reactivity was more reliably detected using the PA induction assay.

Reactivity of children with non-inflammatory diseases was lower than that of healthy adults. Whether these children produced less lymphokine or had relatively insensitive indicator cells is not known. Reactivity could be detected in only 4 of 7 cord bloods and this observation is consistent with previous reports that cord blood and newborns have low levels of lymphokine production in response to immune stimulation (Stiehm et al., 1979). Results from the patients with the Down syndrome are characteristic of these patients' immunodeficiencies (Levin et al., 1979).

Measurement of PA induction is a sensitive assay for cell-mediated immunity. The culture and enzyme assay techniques used permit assay of enzyme induction under 10-20 different conditions using cells obtained from $10 \mathrm{ml}$ of blood in children. While it is more practical to assay for the LIF response to Con A for routine evaluation of non-specific immune responses, the PA induction assay may be valuable at analyzing subtle cell-mediated immune reactivity and autoreactivity. Immunologic PA induction could be detected reliably in patients with active JRA where lymphokine production has been observed to be abnormal (Ellsworth, J.D., L.D. Stein, P.J. Thebert, C.G. Ragsdale, D.B. Sullivan and J.T. Cassidy, submitted). The PA induction assay is currently being further evaluated in comparison with LIF in studies of autoimmunity.

\section{References}

Ackerman, S.K. and S.D. Douglas, 1978, J. Immunol. 120, 1372.

Gordon, S., Z. Werb and Z.A. Cohn, 1976, in: In Vitro Methods in Cell-Mediated and Tumour Immunity, eds. B.R. Bloom and J.R. David (Academic Press, New York) p. 341.

Gorski, A.J., B. Dupont, J.A. Hansen and R.A. Good, 1975, Proc. Natl. Acad. Sci. U.S.A. $72,3197$.

Granelli-Piperno, A., J.-D. Vassalli and E. Reich, 1977, J. Exp. Med. 146, 1693.

Greineder, D.K., K.J. Connorton and J.R. David, 1979, J. Immunol. 123, 2808.

Hamilton, J.A., J.B. Zabriskie, L.B. Lachman and Y.-S. Chen, 1982, J. Exp. Med. 155, 1702.

Klimetzek, V. and C. Sorg, 1977, Eur. J. Immunol. 7, 185.

Levin, S.M., Z. Schlesinger, Z. Handzel, T. Hahn, Y. Altmann, B. Czernobilsky and J. Boss, 1979 , Pediatrics 63, 80 .

McCoy, J.L., J.A. Braatz, R.S. Ames and R.B. Heberman, 1980, J. Immunol. 124, 2786.

Morrison, D.C. and D.M. Jacobs, 1976, Immunochemistry 13, 813.

Sher, M.R., J.S. Schultz, C.G. Ragsdale, J.J. Kapur, D.B. Sullivan and J.T. Cassidy, 1985, J. Rheumatol., in press. 
Sorg, C., C. Neumann, V. Klimetzek and D. Hannich, 1980, in: Mononuclear Phagocytes. Functional Aspects, ed. R. Van Furth (Martinus Nijhoff, The Hague) p. 539.

Stiehm, E.R., H.S. Winter and Y.J. Bryson, 1979, Pediatrics 64 (Suppl.), 814.

Tucker, S.B., R.V. Pierre and R.E. Jordan. 1977, J. Immunol. Methods 14, 267.

Vassalli, J.-D. and E. Reich, 1977, J. Exp. Med. 145, 429.

Vassalli, J.-D., J. Hamilton and E. Reich. 1977, Cell 11, 695.

Wood, D.D., and P.M. Cameron, 1978, J. Immunol. 121, 53. 